\title{
A DEAC-HACKERS ESPORT SZAKOSZTÁLY MESTERSÉGES INTELLIGENCIA OKTATÁSI ÉS KUTATÁSI ELKÉPZELÉSE A MINECRAFTBAN
}

\section{Szerzők:}

Bátfai Norbert (PhD)

Debreceni Egyetem

Csukonyi Csilla (PhD)

Debreceni Egyetem

Papp Dávid (MA hallgató)

Debreceni Egyetem

\section{Lektorok:}

Kozma Tamás (DSc)

Debreceni Egyetem

Z. Karvalics László (PhD)

Szegedi Tudományegyetem

...és további két anonim lektor

Hermann Csaba (PTI BSc hallgató)

Debreceni Egyetem

Deákné Osvald Erika

Debreceni Szakképzési Centrum Irinyi János

Szakgimnáziuma és Szakközépiskolája

Győri Krisztina (MA hallgató)

Debreceni Egyetem

Első szerző e-mail címe:

batfai.norbert@inf.unideb.hu

\section{Absztrakt}

A népszerű tömeges többszereplős számítógépes játékok használata a mesterséges általános intelligencia kutatásban tipikus napjainkban, mivel ezek a játékok ideális terepet biztosítanak az AGI ágensek teszteléséhez. A Microsoft például a Minecraftot használja erre a célra. 2020 eleje óta már a DEAC-Hackersben is lehet Minecraftozni. A DEAC-Hackers a Debreceni Egyetem Atlétikai Clubjának (DEAC) esport szakosztálya. Jelen közleményünkben vázoljuk esport szakosztályunk mesterséges intelligencia oktatási és kutatási elképzelését a Minecraftban.

Kulcsszavak: AGI, Minecraft, oktatás, esport, programozás

Diszciplína: informatika 


\begin{abstract}
THE DEAC-HACKERS ESPORT DEPARTMENT'S EDUCATION AND RESEARCH CONCEPT IN AI IN MINECRAFT

The use of famous massively multiplayer computer games is quite common in AGI (artificial general intelligence) research today. Because these games can provide an ideal environment for testing of AGI agents. For example, Microsoft uses Minecraft for this purpose. From the beginning of 2020, it has already been possible to play Minecraft in DEAC-Hackers too. DEAC-Hackers is the esport department of the University of Debrecen Athletic Club (DEAC). In this paper we outline our esport department education and research concept in AI in Minecraft.
\end{abstract}

Keywords: AGI, Minecraft, education, esport, programming

Disciplines: informatics

Bátfai Norbert, Csukonyi Csilla, Papp Dávid, Hermann Csaba, Deákné Osvald Erika és Győri Krisztina (2020): A DEAC-Hackers esport szakosztály mesterséges intelligencia oktatási és kutatási elképzelése a Minecraftban. Mesterséges intelligencia - interdiszciplináris folyóirat, II. évf. 2020/1. szám. 95-109. doi: 10.35406/MI.2020.1.95

A DEAC-Hackers, a DEAC esport szakosztálya (web: Net1), 2017 szeptem-berében alakult meg (Bátfai és tsai., 2018a). Küldetésünk része, hogy nem csupán egy speciális sport, az esport szakosztálya vagyunk, hanem egyfajta szellemi múhelyként (szakosztályunk például az MI koalíció 127. csatlakozó tagja) is funkcionálunk. Ennek megfelelően az esporttal kapcsolatos kuta-tások mentén is exponálnak játékosaink vagy a körénk csoportosuló kutatók. Fókuszban például az információelméleti alapokra is helyezhető esportolók mérésével (Bátfai és tsai., 2018b; Bátfai és tsai. 2019a) vagy különös tekintettel a mesterséges intelligencia és a játékok kapcsolatára (Bátfai, 2018; Bátfai, 2019a; Bátfai és tsai., 2019b). Vágyunk az Asimov (1966) bevezette robotpszichológia (Bátfai, 2016) tartalmi kitöltése. Hitünk szerint (Bátfai, 2019b) ebben az irányba az esport olyan katalizátor lehet, mint a maga idejében az írás volt (Jaynes, 1986) a kétkamarás tudat jaynesi összeomlásánál (Jaynes, 1976), avagy a mai emberi mentális berendezkedés, a „mi” kialakulásánál. Végső soron azt várjuk, hogy az esport lesz az a társadalmi szinten is értelmezhető tevékenység, amely előidézi az emberi kognitív fejlődés donaldi szintű és Donald (2001, 328. o.) általa vizionált elkövetkező fejlődési állapotát. Ebbe az irányba mutatnak a (Diuk és tsai., 2012) szerinti értelemben introspektívnek értelmezhető játékok fejlesztésének igénye mentén koncepcióban megfogalmazott (Bátfai, 2019b), illetve konk- 
rétan a Paszigráfia Rapszódia (Bátfai és Bátfai, 2019) alapú kutatásaink, ám a jelen munkában ezeket közvetlenül nem tárgyaljuk.

A jelen közlemény apropója, hogy a DEAC-Hackers 2019/2020 vezetőségi döntése alapján már a DEAC-ban is, azaz igazolt amatőr sportolóként lehet Minecraftozni. Miért érdekes a mesterséges intelligencia (MI) kutatás szempontjából a Minecraft? Mert a jelenkori, aktuális MI áttörés - melyet köthetünk a Google DeepMind 2015-ös „ATARIs" Nature folyóiratbeli cikkéhez, melyben Mnih és tsai (2015) arról tudósítanak, hogy megerő-sítéses tanulásos ágens programjuk számos ATARI-s játékban a humán játékosok játékerejét immár felülmúlja - óta tendencia, hogy a terület meghatározó cégeinek saját AGI kutatási fókuszpontjaik egyike egyegy népszerű játék köré szerveződik. A Microsoft esetében ez a játék pedig éppen a Minecraft (Net2), annak is egy modja, a nyílt forráskódú,a GitHub tárolón elérhető Microsoft/MALMÖ projekt (Johnson és tsai. 2016, lásd: Net3).

A DEAC-Hackersben szeretnénk játszani ezt a játékot, közösségépítő és kompetitív (esport) jelleggel is. Továbbá szeretnénk az informatika és a programozás oktatását segíteni a játékra építve, ide értve a Nagyerdei Stadionban várhatóan beinduló igazolt gyerekekkel (és megjegyezhetjük, hogy az időbeli spektrum másik végén az idősekkel is) történô foglalkozást, általános és középiskolai szakköröket. Végül szeretnénk kutatás-fejlesztési tevékenységet is kifejteni, konkrétan az említett MALMÖ alapokon az AGI területén és ezeket az erőfeszítéseket a felsőokta- tásban, ugyancsak a programozás oktatásában hasznosítani. Közleményünk további szerkezete ezt a hármas célt képezi le.

\section{A játék}

A Minecraft alapú közösségépítést máris megkezdtük, ennek alapja egyrészt a megválasztott három egymásmellé rendelt (a jelen közleményben is társszerzőként résztvevő, lásd majd a köszönet részben részletezve) DEAC-Hackers középvezető, a játék szakértői. Másrészt az Informatikai Karon két próbaüzemben tartott „Vanilla” Java Edition Server (Net4) szerver, melyhez a Minecraft Java Edition (Net5) játékot megvásárolók tudnak a vásárolt profiljukkal csatlakozni. Ez a megszorítás természetesen egy szúkebb közösségi keresztmetszetet jelent, de ennélfogva védi is a formálódó közösséget. S valóban számos olyan ér-deklődő van, aki nem tud csatlakozni, mert például nincs érvényes (Minecraft account) profilja, vagy nem kompatibilis platformról játssza a Minacraftot.

Megjegyezhetjük, hogy ez a megvásárolt Javás kliens ugyanúgy letölthető és futtatható GNU/Linux és MS Windows 10 rendszereken is.

A két szerver üzemeltetésével viszont még nem is a közösségépítés a fő cél, sokkal inkább csak a kezdeti tapasztalatok megszerzése. További fontos szempont, hogy ilyen felállásban semmilyen jogi vagy licencmérnöki kérdés nem merül fel, tehát a Minecraft játék játszását továbbra is így tervezzük. Nekünk, mint esport szakosztálynak kiemelt fontosságú, hogy semmilyen jogot ne sértsünk a játékunkkal. 
A „Vanilla” szerver hátránya, hogy nem támogatja a pluginok használatát. Ennélfogva egy ilyen hiányzó szolgáltatás lehet például a futtatott világok kényelmes és felgyorsított szerkesztése (időben nem mindegy, hogy téglákként építünk fel egy több ezer kőből álló piramist, vagy egyetlen parancs kiadásával), amit mondjuk például a WorldEdit (Net6) plugin tudna biztosítani.

Megjegyezhetjük, hogy magunk is tettünk egy kísérletet például a PaperMC (Net7) szerverrel és az említett pluginnel és technikailag a világok a szerverek között könnyen mozgathatóak. Ezért lehet érdekes licencmérnöki szempontból majd a továbbiakban körüljárni olyan kérdéseket, hogy nem sértene-e bármi licencet egy olyan gyakorlat, hogy lokális gépen a „fóépítészek” pluginolt szerveren szer-kesztenék a világot, amit aztán az internetes „Vanilla” szerverekre adatként másolnának fel.

$\mathrm{Az}$ említett két példányban futtatott „Vanilla” szerver program a „DEACHackers 2.0" (193.6.135.126:8080) és a „Debrecen 2.0” (193.6.135.126:10007) nevü világokat szolgáltatja. Előbbi egy teljesen szabad építésű fantáziavilág, utóbbi jóval kötöttebb, itt az építés „építési engedélyhez kötött”. A játékos megadja a valódi lakhelyének egy befoglaló téglalapjának GPS koordinátáit, amelyet mi a Debrecen 2.0 világbeli koordinátákra konvertálunk (a két koordináta elég információt ad az építendő objektum síkbeli tájolásához, konkrétan például, hogy a játékban is abból az ablakból látszódjon a napfelkelte, mint a valóságban). A játékos ide teleportálva bejárható méretben fel- építheti a lakhelyét, vagy iskoláját, vagy egy közösségi teret, például egy parkot és sorolhatnánk. Fontos a bejárhatóság, mert ez egy hátborzongatóan izgalmas játékélményt ad.

A Debrecen név némiképpen félrevezető, hiszen a használt Mercator projekcióval a bolygó tetszőleges pontját le tudjuk képezni a játékbeli koordinátákra, azaz az építendő objektum bárhol lehet. Az 1. ábra az elsőként, a 2. és a 3. ábra a másodikként említett világunk néhány pillanatfelvételét mutatja.

Tekintettel arra, hogy a Minecraftban létrehozott házak, otthonok GPS koordinátájából az azt létrehozó személyek beazonosíthatóak lesznek, a GPS koordináták átadásakor GDPR nyilatkozatot tesznek, hogy az információk feltüntetéséhez (melyből a személy azonosságára fény derülhet) hozzájárulnak.

A tizenéves korosztályban már itt a játéktevékenység során megalapozható a számítógépnek nemcsak élvezeti cikként, hanem munkaeszközként történő használata. A játékbeli saját karakter skínjeinek fejlesztése tipikusan ilyen feladat, ez egy képszerkesztő, például a Linux és Windows rendszerekre is letölthető GIMP használatát jelenti.

Ezen felül remek feladat lehet még a játékbeli elemek felüldefiniálása, ez vagy a GIMP használatával textúrázást, vagy valamilyen 3D modellező programmal JSON-ba kiexportált 3D-s modell készítését jelenti.

Utóbbira láthatunk egy példát a ModelCreator (Net8) szerkesztő használatáról, ahol egy új sisak modellt készítünk a videóban (Net9). 
1. ábra Bátfai Margaréta Niobé épitése a Nagyerdei Stadionba tervezett esport komplexumról a DEACHackers 2.0 világban. * Forrás: saját képernyöfelvétel a Minecraft játszása során.

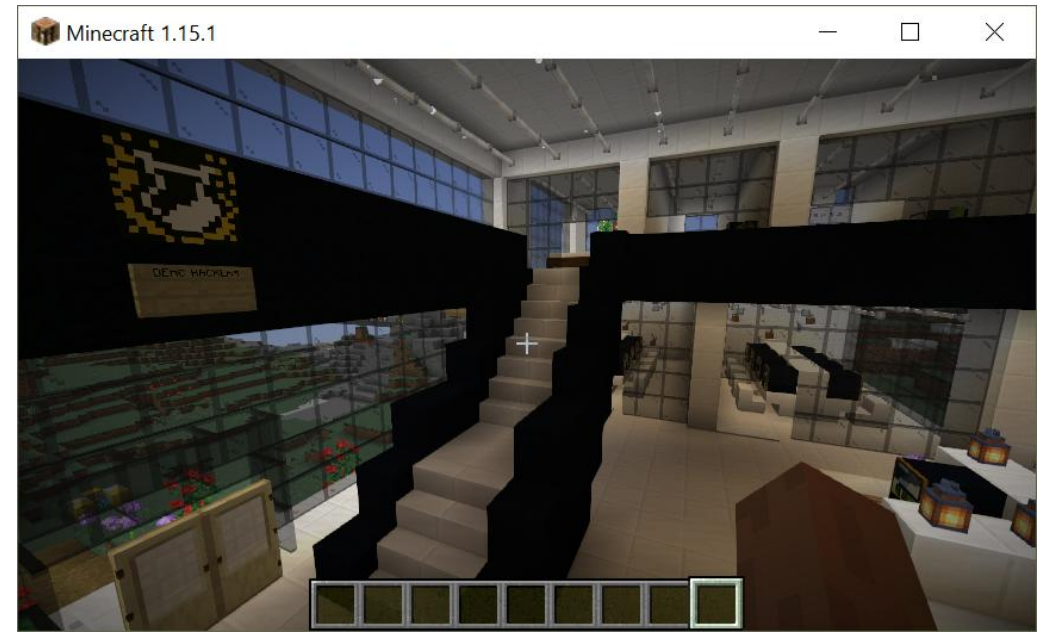

*Az építés a Novák Róbert terveiről Bács Zoltán által közzétett képek alapján készült: https://index.hu/techtud/2019/11/21/a_debreceni_egyetem_is_beszall_az_e-sportba.

2. ábra A Bátfai család háza a Debrecen 2.0 világban. * Forrás: saját képernyöfelvétel a Minecraft játszása során.

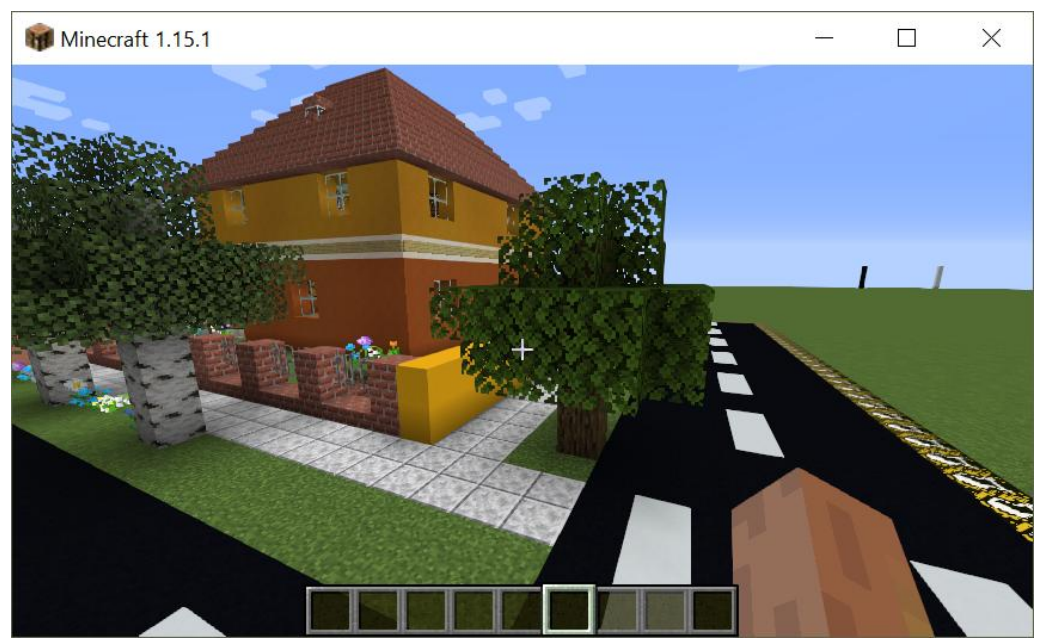

*A ház oldalai nem illeszkednek pontosan az észak-dél és kelet-nyugat tengelyekre, viszont a Minecraftban építeni így kényelmes és életszerü. Ez nyilvánvalóan hibákhoz vezethet, ahogyan a kép jobb oldalán látszó két oszlop jelzi: a ház jobb oldalán lévő útnak e két oszlop között kellene teljesen egyenesen átvezetnie a távolban. Erre Bátfai Nándor Benjáminnal közös megoldásunk, hogy a valóság kis szigeteit építjük fel, melyeket a képen „DEAC”-os blokkok határolnak, s majd a szomszédok 5-6 téglával jobbra tolva kezdenek a saját portájuk építésébe, ők is csak a lokális kapcsolatokra figyelve a valóság saját szigetének kialakításánál. Ekképpen eljárva, ez a világ a lokális kis valóságokkal „leparkettázott” (ilyenek hálózatából álló) világ lesz. 
3. ábra A Bátfai család konyhája, jól látható, hogy az épités teljesiti a megkövetelt bejárhatóságot. Forrás: saját képernyöfelvétel a Minecraft játszása során.

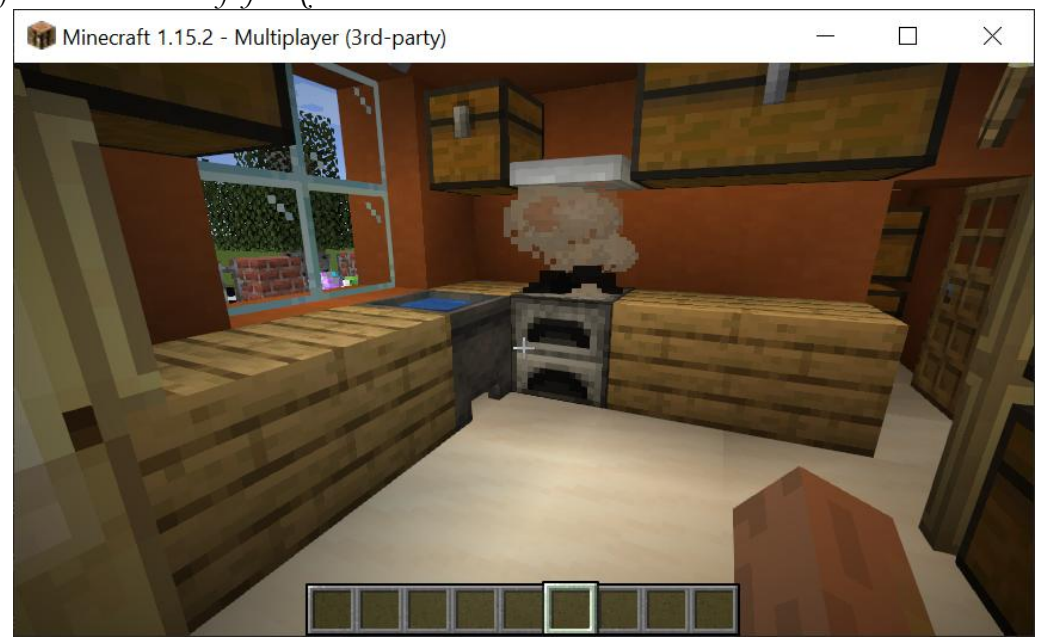

A 3D nyomtatás világa felé lépve akár egy ilyen szerkesztő alkalmazásának megvizsgálása is érdekes lehet a programozás felé haladva, föleg, ha például arra gondolunk, hogy a Tinkercad tud Minecraftba exportálni (Net10).

\section{A programozás oktatása}

A programozás oktatásában a legnagyobb hangsúlyt időben a középiskola derekától a felsőoktatás első év végéig tartó időszakára fektetnénk, mivel megérzésünk, hogy a Geary (1998, 156. o.) által „matematikai gondolkodási faktor"-nak nevezett megfelelő faktor létezhet (és ugyanebben az időablakban létezhet) a programozás tanulásában is.

Ennek megfelelően szakköröket fogunk tartani középiskolásoknak. Ennek nem Mine- craft specifikus előtanulmányaként Bátfai és tsai. (2019c) mûvét említhetnénk.

A MALMÖ projekt lehetőséget ad a Minecraft karakterünk ágens programozására. Ennek során használhatjuk a játék játszása közben megismert absztrakciós szintet, konkrétan lekérdezhetjük az ágensünket befoglaló kockát és megvizsgálhatjuk, hogy ennek a kockának a blokkjai melyek (például kő vagy levegő blokkok és sorolhatnánk, lásd a MALMÖ projekt dokumentációját). A másik lehetőség, ami már megfelel az MI mai tárgyalásának, hogy az ágens is ugyanazt a képernyőképet látja és kapja meg feldolgozásra, mint amit a gép elé leülő humán játékos is lát (ahogyan a bevezetésben hivatkozott „ATARI-s" cikkben is eljártak). Az ágens feladata a látott képernyőképekből kiindulva dolgozni: valamilyen absztrakciót, modellt felépíteni, 
vagy éppen Q-tanulást alkalmazni. Családi körben mindkét esetben voltak már kezdeti próbálkozásaink, ahogyan ezt például a Net11 és a Net12 videókon láthatjuk. A MALMÖ projekt egy-egy minta $\mathrm{C}++$, Java és C\# példával, illetve egy teljes Python bevezetô példatárral rendelkezik, kezdve a befoglaló kocka lekérdezésétől a Q-tanulásig, így a középiskolai szakkörök választott programozási nyelve célszerūen a Python lesz.

A felsőoktatásban több lehetőségünk adódik a hangsúlyok elhelyezésére a MAL-MÖ projekt felhasználása tekintetében. Bevezető jellegú programozás kurzusokban, mint ahogyan nekünk a „Magas szintű programozási nyelvek" tárgyak kapcsán ilyen laborgyakorlatokon van lehetőségünk expo-nálni, szempont lehet, hogy a fejlesztendő ágens programot mind a négy említett nyelven valósítsa meg a tárggyal kapcsolatos otthoni programozási feladat kapcsán a hallgató. Egy gépi tanulásos kurzus inkább a képi bemenetet kapó ágens mélytanulását tűzheti célul. Előbbi esetben programozási versenyben is gondolkozunk, amelyről a következő pont-ban láthatjuk majd, hogy egyáltalán nem idegen a MALMÖ projekt fejlődésében, sőt tipikus. A verseny alapja lehetne például, hogy az ágensek egy „battle royale” jellegű térben tevékenykedjenek. Egy ilyen kísérletünket mutatja a 4. ábra, ahol a folyamatosan lecsorgó láva adja a megszokott és közismert battle royale élményt. Folytonosságot jelenthet a szakköri és az egyetemi szint között a Minecraft felhasználásában, hogy középiskolai szakkörön magának egy ilyen pályának a megalkotása akár már önmagában is egy érdekes célfeladat lehet.

4. ábra Egy esettanulmány battle royale jellegü mini játék kialakitására a Minecraft MALMÖ projektben. Forrás: saját képernyófelvétel a MALMÖ futtatása során.

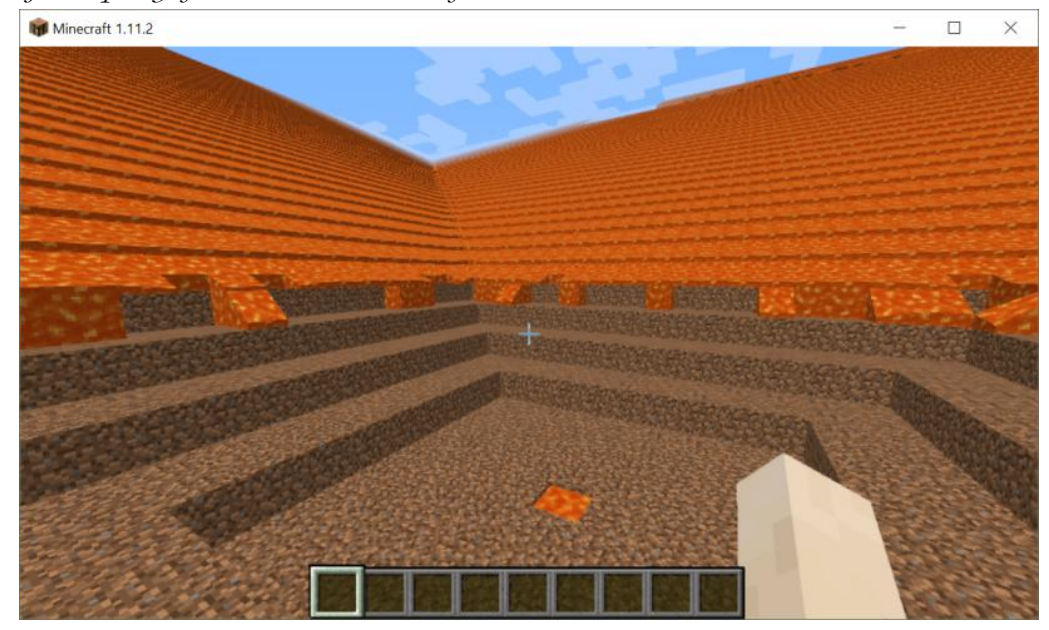




\section{A kutatás}

A bevezetőben említett „ATARI-s” cikk óta tendencia, hogy az MI meghatározó kutatási és ipari szereplői nagy játékcímek köré szervezik kutatásaikat (Hernandez-Orallo és tsai., 2017). A Microsoft ilyen platformja a már ugyancsak említett és hivatkozott Minecraft központú MALMÖ projekt. A projektet visszatekintve éves ciklusokban versenyek kísérik:

-2019-ben a MineRL (Net13), melyről a Nature tudósított (Hsu, 2019). A verseny fókuszába a klasszikus megerősítéses tanulással szemben az utánzásos tanulást állították (Guss és tsai., 2019a), ahol az utánzott viselkedés forrása a nyilvános szerverükön (mc.minerl.io) emberi játékosok által játszott játék (túlélő módban, illetve 6 célfeladat kreatív módban) sztenderd adathalmazba rendezett formája (Guss és tsai. 2019b).

- Ezt megelőzően, 2018-ban a MARLO (Net14) a multiágenses megerősítéses tanulásról szólt (Perez-Liebana és tsai., 2019) a játékban szervezett három célfeladattal: mob vadászattal, építő csatával és kincsvadászattal.

- 2017-ben pedig az együttmúködő ágensek volt a téma (Net15). Konkrétan egy MALMÖ Minecraftbeli malac vadászat mini játékkal.

Ezeken túl további irodalmi tételek is fellelhetóek a szakirodalomban, ahol a Minecraft, mint tesztkörnyezet van használatban. Geiger, Hofmann és Schölkopf (2016) példá- ul már említi az, idézzük: „fizikai világ univerzális reprezentálásánál” a GPS használatát. Gépi tanulás tekintetében, tipikusan a mély megerősítéses tanulás adott esetekbeli javításaira, a Minecraftot használva kipróbálásra fókuszálnak (Monfort és tsai., 2017; Liu, Dogan és Hofmann, 2016; Beck és tsai., 2020).

A „Minacraft pszichológiai alkalmazása képesség és készségfelmérésre a mesterséges intelligencia területén" témában a Michigani Egyetemen (Oh és tsai., 2016) Minecraft játékprogramban alkotott labirintusokkal vizsgálják a mesterséges intelligencia ágensek kognitív kapacitását és képességeit. Nagyon hasonlóan ahhoz, ahogyan a közlekedés-, munka- és sport-pszichológiában a fokozott interaktivitást igénylő tesztek mérik fel a humán vizsgálati személyek kompetencia szintjét (lásd Vienna Test System, DPTR - Debreceni Pszichológiai Tesztrendszer). A kiindulási alap az volt, hogy való fizikai környezetben nem igazán mérhetők fel, illetve lehet tanítani a mesterséges intelligencia ágenseket, mivel ebben a közegben a tárgyak nem állandók, kitakarások keletkeznek, változhatnak például a fényviszonyok. Viszont a Minecraft online kontrollált világa jobban megfelel az elvárásoknak, mivel labirintusokat aránylag könnyű létrehozni benne, és a közeg rugalmassága pedig egyre bonyolultabb és nehezebb tanulási feladatok megalkotását is lehetővé teszi. Emellett érdemes kiemelni, hogy a vizsgálatok során a mesterséges intelligencia kontextusfüggő memóriával kiegészített megerôsítéses mélytanulását használtak, azt tapasztalták így hatékonyabban oldják meg a 
feladatokat, járulékos eredményként kiemelhető, hogy a biztonságos online közegben az MI etikai kérdései is eredményesen vizsgálhatók.

A Minecraft a problémamegoldó képesség és a kreativitás fejlesztésére is szolgálhat, ha megfelelően alkalmazzák például a gyermekek esetében az oktatáson belül. Cipollone, Schifter és Moffat (2014) kisgyerekek kreativitásának fejlesztésére használták fel a videojátékot azáltal, hogy kisfilmek (úgynevezett Machinimák) készítésére kérték meg őket. Risberg (2015) pedig a kreativitáson kívül kiemelte a probléma megoldási jellegét a Minecraftnak, a túlélő mód által támasztott nehézségek és kihívások leküzdéséről, receptek illetve a rendszer megfelelő alkalmazásáról beszélve.

További izgalmas, részben pszichológiai projekt a ToMCAT (Net16), melynek célja az emberrel együttmúködni képes ágensek fejlesztésének kutatása, ahol tesztkörnyezetként ugyancsak a Minecraftot használják.

A szakirodalmi kitekintést az idősek és a játékok kapcsolatával zárjuk le, példaképpen Schutter, Black és Nap (2015) munkáját említve, ahol konktétan a Minecraft idősek számára szóló oktatását vizsgálták.

Ezeket a hivatkozott, a gépi tanulástól a pszichológiáig szóródó eredményeket nyilvánvalóan követnünk kell, mert erre fejlődik a világ, ez a fejlődés iránya. Viszont John Carmackot (a Doom alkotója) idézve és értelmezve: „Victorian Gentleman Scientist” módjára „Pascal kirablásának” (Pascal's mugging, lásd még: Net17 - Carmack, 2019) logikájával (azaz legyen az bármennyire is va- lószínűtlen) meg kell adjuk az esélyt az AGI kutatásban a saját ötletek valamilyen szintű átgondolásának. Ezt tehetjük mi is, például a Paszigráfia Rapszódia (PaRa) kapcsán.

A Paszigráfia Rapszódia (Net18), egy elsőrendű klasszikus logikai formális nyelven alapuló grafikus, tehát csakis „írott” formában tervezett mesterséges nyelv. Jelenlegi grafikus reprezentációiban $n$ dimenziós pöttyözött hiper-kockák formájában jelenik meg. Amelyet a gyakorlatban 2 és 3 dimenziós LuaLaTeX és OpenGL megvalósítások adnak vissza.

Ennélfogva kézenfekvő lehetne egy olyan Minecraft világot építeni, melyben a nyelv pöttyözött 3D kockái Minecraft blokkok. Itt azonnali nehézség, hogy a nyelvben a hiperkockák minden oldalára tetszőleges finomságú mxm-es lapokon (tehát m tetszőlegesen nagy lehet) történik a „pöttyözés”. Ezért az esetleges Minecraftbeli PaRa blokkok helyett inkább az egyéni blokknak tervezett 3D-s objektumok jöhetnének számításba.

Megjegyezhetjük, hogy maga a „pöttyözős” reprezentáció ötlete (Bátfai és tsai. 2019b) a szemantikus MNIST munkában gyökerezik.

Ha nem is $\mathrm{PaRa}$ alapon, de a gépi tanulás vizualizálása a Minecraftban is egy izgalmas kihívás, korábban „Agyfalu” névvel illettük az ilyen érdeklődésünk kifejeződését - lásd például Net19 videót.

Egy klasszikusabb további kutatási irány lehet korábbi közlekedés szimulációs, OpenStreetMap (OSM, lásd: Net20) alapú, OOCWC (rObOCar World Championship, Robotautó Világbajnokság) törekvéseink 
(Bátfai és tsai., 2015; Net21 és Net22) esetleges Minecraftba történő elemzésének megvizsgálása.

\section{Konklúziók}

Közleményünkben áttekintettük, hogy milyen lehetőségek látszanak a DEAC-Hackers esport szakosztály horizontján a Minecrafttal kapcsolatos játék, programozás oktatás és kutatás tekintetében. Játék terén a GPS alapú Debrecen 2.0 világ építését egy nagyon izgalmas opciónak tartjuk. Magát a szerverek közötti „világ másolást” és szerkesztést is olyan motivációval néztük meg, hogy ha az OSM térképadatokat Minecraft világbeli adatokká konvertálnánk, akkor azokat hogyan tudnánk a létező világokba beszerkeszteni. Sőt, eleve találtunk olyan projekteket, melyek ezt a konverziót el is végzik. Ilyen például a Geocraft (Net23), amellyel Debrecen egy részét meg is tudtuk nézni a Minecrafttal beolvasva és rendben meg is jelenítette a térkép adatait a világban. Mi azonban mégsem ezt választottuk, hanem azt a megoldást, hogy GPS koordinátákból kiindulva a valóság említett kis szigeteit kézzel építjük fel a játékban. Ennek okait a közlemény tárgyalásában kifejtettük.

Megjegyezhetjük, hogy az imént hivatkozott geocraft projekttel részben az OSM, részben a terep LIDAR lézeres felmérésére építve egész Nagy Britannia bármely része letükrözhető a Minecraftba úgy, hogy a domborzati viszonyok is megjelennek (ennek kapcsán lásd a hivatkozott projekt lapját).
A Geocraft.nl (Net24) projekt célja pedig egész Hollandia felépítése. Ugyanitt említhetjük, bár már nem geocraft alapon Budapest jeles építményeinek megvalósítását (Net25).

A GPS-es irányvonal mentén pedig a most éppen aktuális Minecraft Earth (Net26) játék megjelenését kell megemlítenünk. Ez a játék a Pokémon GO (Net27) játékhoz teljesen hasonló játékélményt ad, ami nem csoda, hiszen mindkét játék OSM térkép alapú. Ám a Minecraftos megjelenés, bár természetes módon, de „kockás” (ezt vö. a 2. ábra feliratának magyarázatával).

Prioritásaink a közeli jövőben egy saját egyetemi MALMÖ alapú verseny kidolgozása egyrészt a programozás oktatásának támogatására, másrészt a gépi tanulással és az AGIval kapcsolatos „Minecraftos” kutatások megkezdésére. A MALMÖ oktatási felhasználásával is hivatkozhatunk követendő példát: a Kaliforniai Állami Egyetem (Irvine) „Projects in AI in Minecraft” című (Net28) kurzusa nagyon jó, követendő példának tûnik.

További prioritásunk az utánpótlás korú gyerekek Minecraft alapú programozás edzésének és az idősek Minecraft játékának a vizsgálata az említett, a Nagyerdei Stadionba tervezett esport komplexumban.

\section{Köszönetnyilvánítás}

A jelen közlemény elkészítését a „Debrecen a kockák origójában" - a DEAC-Hackers esport szakosztály Minecrafttal kapcsolatos koncepciója című, szintén a szerzők (részhalmaza) által készített belső munkaanyag inspirálta. Kö- 
szönjük a játékbeli, említett DEAC és Debrecen világok építését a DEACHMinecraft facebook-csoport (Net29) tagjainak és kiemelten Bátfai Margaréta Niobé (Minecraftbeli IGN: PusziNyuszi12), Bátfai Nándor Benjámin (IGN: NandiFighter), Bátfai Mátyás Bendegúz, Deák Martin Ádám (IGN: AdamHuszar) és Deák Kevin (IGN: DeakHuszar) tanuló, igazolt DEAC-hackers játékosoknak.

A társszerzők hozzájárulása a kézirathoz: Bátfai Norbert (DEAC-Hackers kutatási vezető, IGN: nb4tf4i) általában a koncepció, a játék, programozás és kutatás részek kidolgozása.

Csukonyi Csilla és Papp Dávid (DEACHackers Minecraft pszichológiai középvezető) pszichológiai aspektusok.

Hermann Csaba (DEAC-Hackers Minecraft kompetitív és programozási középvezető) az alternatív szerverek és pluginek bemutatása.

Deákné Osvald Erika (DEAC-Hackers utánpótlás-nevelési és tehetséggondozási szakmai vezetô) a stadionbeli leendő komplexumban a Minecraft foglalkozások tervezése és a Debrecen 2.0 világ GDPR kérdései.

Győry Krisztina (DEAC-Hackers Minecraft nevelési középvezető) oktatási aspektusok.

\section{Irodalom}

Asimov, I. (1966). Én, a robot. Kossuth Kiadó, Budapest.

Bátfai, N. (2016). How to Become a Robopsychologist, Letöltés: 2020.04.25. Web:
https://github.com/nbatfai/Robopsycho logy/files/169195/robopsychology.pdf

Bátfai, N. (2018). A játékok és a mesterséges intelligencia mint a kultúra jövője - egy kísérlet a szubjektivitás elméletének kialakítására. Információs Társadalom, 18(2), 28 - 40. Doi: 10.22503/inftars.XVIII. 2018.2.2

Bátfai, N. (2019a). Esport kultúra: a mesterséges intelligencia kognitív evolúciós értelmezése, nem publikált kézirat. Letöltés: 2020.04.25. Web: https://gitlab.com/ nbatfai/pasigraphyrhapsody/blob/master $\angle$ para/docs/hungarian_mitel.pdf

Bátfai, N. (2019b). A játék vége, Debreceni Egyetem és a DJ Digitális Sport Tudásközpont, Országos Esport Konferencia, (a kiadványba beküldött kézirat)

Bátfai, N., Besenczi, R., Szabó, J., Jeszenszky, P., Buda, A., Jármi, L., Lovas, R., Pál, M., Bogacsovics, G. és Tóthné Kovács, E. (2018a). DEAC-Hackers: játszó hackerek, hackelő játékosok. Információs Társadalom, 18(1), 132-146. Doi: 10.22503/inftars. XVIII.2018.1.9

Bátfai, N., Bogacsovics, G., Paszerbovics, R., Antal, A., Czevár, I., Kelemen, V. és Besenczi, R. (2018b). E-sportolók mérése. Információs Társadalom, 18(1), 147-155. Doi: 10.22503/inftars.XVIII.2018.1.10

Batfai, N., Papp, D., Besenczi, R., Bogacsovics, G. és Veres, D. (2019a). Benchmarking Cognitive Abilities of the Brain with the Event of Losing the Character in Computer Games. Studia Universitatis Babes-Bolyai Informatica, 64(1), 15-25. Doi: 10.24193/subbi.2019.1.02 
Bátfai, N., Papp, D. Bogacsovics, G., Szabó, M., Simkó, V. Sz., Bersenszki, M., Szabó, G., Kovács, L., Kovács, F. és Varga, E. Sz. (2019b). Object file system software experiments about the notion of number in humans and machines, Cognition, Brain, Behavior. An Inter-disciplinary Journal, XXIII(4), 257-280. Doi: 10.24193/cbb.2019.23.15

Bátfai, N., Csukonyi, Cs., Papp, D., Szabó J., Tóth L. Sz. és Kovács F. (2019c). HKKHackers: a halálos robotfegyverek és az asimovi három törvény. Hadtudományi Szemle, közlésre elfogadva

Bátfai, N. és Bátfai, N. B. (2019). Az esport kultúra nyelve. Letöltés: 2020.04.25. Web: https://gitlab.com/nbatfai/pasigraphyrha psody/blob/master/para/docs/para pro g_guide.pdf

Bátfai, N., Besenczi, R., Mamenyák, A. és Ispány, M. (2015). OOCWC: The robocar world championship initiative, Telecommunications (ConTEL), 2015 IEEE 13th International Conference on, 1 - 6, Doi: 10.1109/ConTEL.2015.7231223

Beck, J., Ciosek, K., Devlin, S., Tschiatschek, S., Zhang, C. és Hofmann, K. (2020). AMRL: Aggregated Memory For Reinforcement Learning, 8th International Conference on Learning Representations. letöltés: 2020. 04.25. Web: https://openreview.net/ forum?id=Bkl7bREtDr

Carmack, J. (2019). John Carmack személyes Facebook lapjának posztja. Letöltés: 2020. 01. 22. Web: https://www.facebook. com/permalink.php?story fbid $=2547632$ $\underline{585471243 \& \mathrm{kid}=100006735798590}$,
Cipollone, M., Schifter, C. és Moffat, R., A. (2014). Minecraft as a creative tool: A case study. International Journal of GameBased Learning. 1-14. Doi: 10.4018/ijgbl. 2014040101

Donald, M. (2001). Az emberi gondolkodás eredete. Osiris Kiadó, Budapest

Diuk, C. G., Slezak, D. F., Raskovsky, I., Sigman, M. és Cecchi, G. A. (2012). A quantitative philology of introspection. Frontiers in integrative neuroscience. 6. 80. Doi: $\underline{10.3389 / \text { fnint. } 2012.00080}$

Geary, D. C. (1998). Biológia, kultúra és a nemzetek közötti különbségek a matematikai képességekben, 147-172, in Robert J. Sternberg, Talia Ben-Zeev, A matematikai gondolkodás természete, Vince Kiadó, Budapest

Geiger, P., Hofmann, K. és Schölkopf, B. (2016). Experimental and causal view on information integration in autonomous agents in Proceedings of the 6th International Workshop on Combinations of Intelligent Methods and Applications, 21-28, Letöltés: 2020.04.25. Web: https://arxiv.org/ abs/1606.04250

Guss, W. H., Codel, C., Hofmann, K., Houghton, B., Kuno, N. S., Milani, S., Mohanty, S., Liebana, D. P., Salakhutdinov, R., Topin, N., Veloso, M. és Wang, W. (2019a). The MineRL Competition on Sample Efficient Reinforcement Learning using Human Priors. Letöltés: 2020.04.25. Web: https://arxiv.org/abs/ $\underline{1904.10079}$

Guss, W. H., Houghton, B., Topin, N., Wang, P., Codel, C., Veloso, M. és 
Salakhutdinov, R. (2019b). MineRL: A Large-Scale Dataset of Minecraft Demonstrations. Letöltés: 2020.04.25. Web: https://arxiv.org/abs/1907.13440

Hernandez-Orallo, J. B. M., Bieger, J., Chmait, N., Dowe, D., Hofmann, K., Plumed, F. Strannegård, C. és Thórisson, K. (2017). A New AI Evaluation Cosmos: Ready to Play the Game?. AI Magazine. 38. 66. Doi: $10.1609 /$ aimag.v38i3.2748

Hsu, J. (2019). AI takes on popular Minecraft game in machine-learning contest. Nature, 575(7784), 583-584. Doi: $10.1038 /$ d41586-019-03630-0

Jaynes, J. (1986). Consciousness and the voices of the mind, Canadian Psychology/Psychologie canadienne, 27(2), 128-148. Doi: $\underline{10.1037 / \mathrm{h} 0080053}$

Jaynes, J. (1976). The origin of consciousness in the breakdown of the bicameral mind. Boston: Houghton Mifflin.

Johnson, M., Hofmann, K., Hutton, T. és Bignell, D. (2016). The Malmo Platform for Artificial Intelligence Experimentation, 25th International Joint Conference on Artificial Intelligence. Letöltés: 2020. 04.25. Web: https://www.ijcai.org/ Proceedings/16/Papers/643.pdf

Liu, T. L., Dogan U. és Hofmann, K. (2016). Decoding multitask $D Q N$ in the world of Minecraft, The 13th European Workshop on Reinforcement Learning. Letöltés: 2020.04.25. Web: https://ewrl.files.word press.com/2016/11/ewrl13-2016submission-29.pdf

Mnih, V., Kavukcuoglu, K., Silver, D., Rusu, A. A., Veness, J., Bellemare, M. G. és
Hassabis, D. (2015). Human-level control through deep reinforcement learning. Nature, 518(7540), 529-533. Doi: $\underline{10.1038 / \text { nature } 14236}$

Monfort, M., Johnson, M., Oliva, A. és Hofmann, K. (2017). Asynchronous Data Aggregation for Training End to End Visual Control Networks, AAMAS '17 Proceedings of the 16th Conference on Autonomous Agents and MultiAgent Systems. Letöltés: 2020.04.25. Web: https://www.micro soft.com/en-us/research/wpcontent/ uploads/2017/05/fp185-monfort-1.pdf

Net1: DEAC-Hackers, a DEAC esport szakosztálya Letöltés: 2020.04.25. Web: http:// www.deac.hu/szakosztalyok/esport

Net2: Minecraft Letöltés: 2020.04.23. Web: https://www.minecraft.net/)

Net3: Malmö projekt. letöltés: 2020.04.23. Web:https://github.com/microsoft/ $\underline{\text { malmo }}$

Net4: „Vanilla” Java Edition server. Letöltés: 2020.04.20. Web: https://www.minecraft. net/en-us/download/server

Net5: Minecraft Java Edition. Letöltés: 2020.04.20. Web: https://www.minecraft. net/en-us/store/minecraft-java-edition

Net6: WorldEdit plugin. Letöltés: 2020.04.20. Web: https://github.com/enginehub/ worldedit

Net7: PaperMC. Letöltés: 2020.04.20. Web: https://github.com/PaperMC/Paper

Net8: ModelCreator. Letöltés: 2020.04.25. Web: https://github.com/MrCrayfish/ ModelCreator 
Net9: Sisak modell késztésének folyamata. Letölrés: 20020.04.25. Web: https:// youtu.be/1WRuHo0QLTg

Net10: Tinkercad. Letöltés: 2020.04.20. Web: https://www.tinkercad.com/minecraft

Net11. Letöltés: 2020.04.25. Web: https:// youtu.be/bAPSu3Rndi8

Net12. Letöltés: 2020.04.25. Web: https:// youtu.be/x52iPOwwMn4

Net13: MibeRL verseny. Letöltés: 2020.04.25. Web: http://minerl.io

Net14: MARLO verseny. Letöltés: 2020.04.25. Web:https://www.crowdai.org/ challenges/marlo-2018

Net15. Letöltés: 2020.04.25. Web: https:// www.microsoft.com/en-us/research/ academic-program/collaborative-aichallenge/

Net16: ToMCAT. Letöltés: 2020.04.25. Web: https://ml4ai.github.io/tomcat

Net17: Pascal's mugging. Letöltés: 2020.04.25. Web: https://en.wikipedia.org/wiki/ Pascal's mugging

Net18: Paszigráfia Rapszódia (PaRa). Letöltés: 2020.04.25. Web: https://gitlab.com/ nbatfai/pasigraphy-rhapsody

Net19. Letöltés: 2020.04.25. Web: https:// youtu.be/ mwauU neDQ

Net20: OpenStreetMap (OSM). Letöltés: 2020.04.25. Web: https://www.open streetmap.org/

Net21. Letöltés: 2020.04.25. Web: https:// youtu.be/DL6iQwPx1Yw

Net22: Robocar emulator. Letöltés: 2020.04.25. Web: https://github.com/nbatfai/robo car-emulator
Net23: Geocraft példa. Letöltés: 2020.04.25. Web: https://github.com/cgutteridge/ geocraft

Net24: Geocraft.nl. Letöltés: 2020.04.25. Web: https://geocraft.nl

Net25. Letöltés: 2020.04.25. Web: https:// www.minebudapest.hu

Net26: Minecraft Earth. Letöltés: 2020.04.25. Web: https://www.minecraft.net/en-us/ about-earth

Net27: Pokémon GO. Letöltés: 2020.04.25. Web: https://www.pokemongo.com

Net28: Projects in AI in Minecraft. Letöltés: 2020.04.25. Web: https://canvas.eee.uci. edu/courses/15949

Net29: DEACHMinecraft facebook-csoport Letöltés: 2020.04.25. Web: https://www. facebook.com/groups/DEACHMinecraf $\mathrm{t} /$

Oh, J., Chockalingam, V., Singh, S. és Lee, H. (2016). Control of Memory, Active Perception, and Action in Minecraft. Letöltés: 2020.04.25. Web: https://arxiv.org/abs/ $\underline{1605.09128}$

Perez-Liebana, D., Hofmann, K., Mohanty, S P., Kuno, N S., Kramer, A. , Devlin, S., Gaina, R D. és Ionita, D. (2019) The Multi-Agent Reinforcement Learning in MalmÖ (MARLÖ) Competition. Letöltés: 2020. 04.25. Web: https://arxiv.org/abs/1901. $\underline{08129}$

Risberg, C. (2015). More than just a video game: tips for using minecraft to personalize the curriculum and promote creativity, collaboration, and problem solving. Illinois Association for Gifted Children Journal. pp. 44-48. 
Schutter, B. D., Black, D.E. és Nap, H. H. (2015). Teacbing Older Adults to Play Minecraft, Foundations of Digital Games Conference At Pacific Grove. Letöltés:
2020.04.25. Web: https://www.research gate.net/publication/285579280 Teachin g Older Adults to Play Minecraft 